\title{
Diversity of the Arthropod edaphic fauna in preserved and managed with pasture areas in Teresina-Piauí-Brazil
}

\author{
Luz, RA., Fontes, LS. *, Cardoso, SRS. and Lima, ÉFB. \\ Departamento de Biologia, Centro de Ciências da Natureza, Universidade Federal do Piauí - UFPI, Campus Ministro \\ Petrônio Portella, CEP 64049-550, Ininga, Teresina, PI, Brazil. \\ *e-mail:lsfontes@uol.com.br
}

Received February 14, 2012 - Accepted August 10, 1212 - Distributed August 31, 2013

(With 2 figures)

\begin{abstract}
The soil fauna plays an important function over the processes of organic matter decomposition, nutrient cycling, ground aeration and fertility. Thus, studies on the composition and structure of such communities are important, considering moreover the lack of information in different regions of Brazil and mainly related to the state of Piauí. This study aimed to evaluate the density and diversity of the soil arthropod fauna in a Cerrado area in preservation conditions and in a pasture area. Both are situated in the city of Teresina, capital of the state of Piauí. Pitfall traps were used for sampling. Five stations with four traps were placed in each area. The traps were constituted by a $500 \mathrm{~mL}$ plastic cup containing a preserving solution made with $70 \%$ alcohol and $40 \%$ formalin. The traps were weekly changed by occasion of the collections. Eight samples were performed in the period between March and April 2007. The results were evaluated using the following variables: number of orders, number of families, total of species and total number of individuals. Evaluation of the Diversity Index and Similarity Coefficient were also performed. As result, the variables and diversity indices were slightly higher in the preserved area. However, the similarity coefficient showed only $10 \%$ similarity between both areas.
\end{abstract}

Keywords: soil, macrofauna, insects, savannah, conservation.

\section{Diversidade de artrópodes da fauna edáfica em área preservada e área manejada com pastagem no município de Teresina-Piaúi-Brasil}

\section{Resumo}

A fauna do solo exerce importante papel nos processos de decomposição da matéria orgânica, ciclos de nutrientes, aeração e fertilidade do solo. Assim, estudos sobre a composição e estrutura dessas comunidades são importantes, considerando, além disso, a escassez de informações nas diferentes regiões do Brasil e principalmente em relação ao estado do Piauí. Este estudo teve como objetivo avaliar a densidade e diversidade da fauna de artrópodes encontrados no solo em uma área de Cerrado em estado de preservação e uma área utilizada com pastagem. Ambas estão situadas no município de Teresina, capital do estado do Piauí. Armadilhas do tipo Pitfall foram utilizadas para amostragem. Cinco estações com quatro armadilhas foram colocadas em cada área. As armadilhas foram constituídas por um copo plástico $(500 \mathrm{~mL})$, contendo uma solução conservante feita de álcool $70 \%$ e formol $40 \%$. As armadilhas foram trocadas semanalmente por ocasião das coletas. Foram realizadas oito coletas entre o período de março e abril de 2007. Os resultados encontrados foram avaliados através das variáveis: número de ordens, número de famílias, total de espécies e número total de indivíduos. A avaliação do Índice de Diversidade e Coeficiente de Similaridade também foi feita. Como resultado, as variáveis estudadas e o índice de diversidade foram levemente maiores na área preservada. Contudo, o Coeficiente de Similaridade mostrou apenas 10\% de semelhança entre as duas áreas.

Palavras-chave: solo, macrofauna, insetos, cerrado, conservação.

\section{Introduction}

Arthropods are abundant in almost all the terrestrial ecosystems, decomposing annually about $20 \%$ of the foliage produced on the planet, and thus, being important in maintaining balance in nature (Samways, 1994). The soil is the natural habitat for a wide range of arthropods, which are responsible for numerous functions, such as nutrient cycling, aeration and fertilization.

The use of soil for different purposes, such as agriculture, may influence its physical, chemical and biological properties. In the biological aspect, it can occur a selection of groups of soil arthropod in addition to altering the abundance and diversity of these. Some insects, for ex- 
ample, interact with other microorganisms, which decompose and mineralize the soil detritus (Höfer et al., 2001), thus contributing to the recycling of nutrients. In this case, these animals can act as converters of soil quality, making it more fertile. When these natural processes disappear, the environmental and socioeconomic costs can be significant (Altieri et al., 2003).

The soil fauna is affected by factors such as quality of organic matter, $\mathrm{pH}$, temperature, humidity, texture, vegetation cover and agricultural practices that promote changes in the abundance and diversity of species, which may cause changes in soil characteristics (Socorras, 1998). Therefore, such fauna is largely used as bioindicators (Paolleti et al., 1996, van Straalen, 1998, Parisi et al., 2005, Santoruffo et al., 2012), and some groups, such as butterflies, beetles and ants, are especially useful in environmental monitoring since they are easily sampled and identified, found all year round, and show fast response to environmental changes (Favero et al., 2011). Thus, studies on the composition, structure, behavior and ecological surveys of these communities are extremely important, considering also the lack of information in different regions of the Country and especially related to the state of Piauí.

This study aimed to evaluate the effect of soil management on the abundance and diversity of fauna associated with the soil, using comparative analysis of the diversity of soil arthropods in an area previously preserved and in a managed area with pasture.

\section{Material and Methods}

The experimental plots consisted of two ecosystems in Teresina, Piauí, Brazil: a preserved area and an area managed with pasture. The first one, with Cerrado vegetation (Figure 1), is situated in Teresina Environmental Park, in an area of 38 hectares. This research station is located at an average altitude of $72.7 \mathrm{~m}$ and $5^{\circ} 02^{\prime} 13^{\prime \prime} \mathrm{S}$ latitude and $42^{\circ} 48^{\prime} 41^{\prime \prime} \mathrm{W}$ longitude. The managed area used in this work was at a farm occupied by pasture (Brachiaria $\mathrm{sp}$.), which had been used in livestock for more than 30 years (Figure 2). This research station is located at an average al-

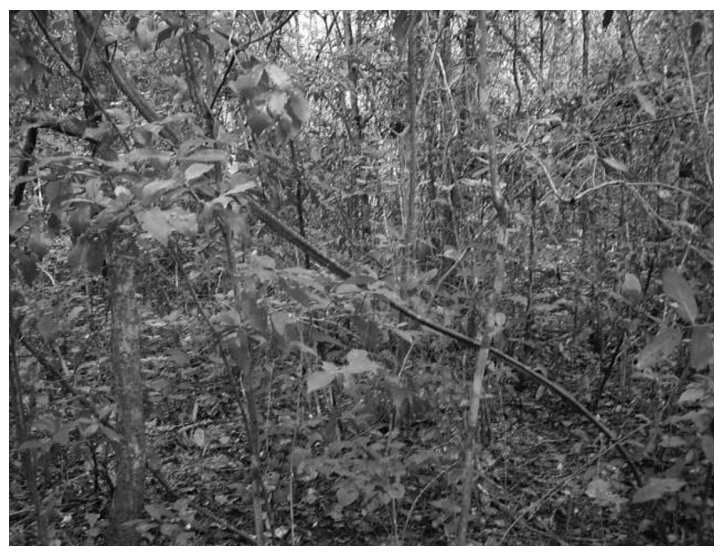

Figure 1 - Partial view of the preserved area.

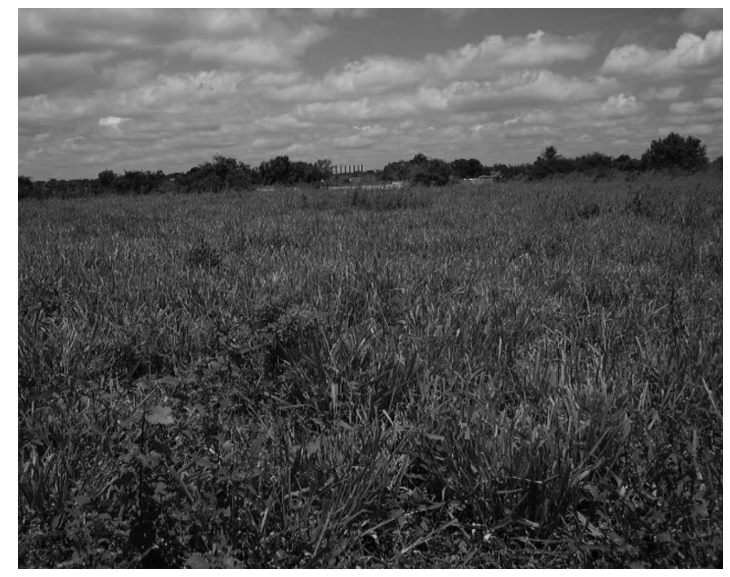

Figure 2 - Partial view of the pasture area.

titude of $60 \mathrm{~m}$ and $5^{\circ} 01^{\prime} 44^{\prime \prime} \mathrm{S}$ latitude and $42^{\circ} 49^{\prime} 37^{\prime \prime} \mathrm{W}$ longitude.

The data on arthropods obtained by pitfall traps were characterized by the following variables: number of orders (NO), number of families (NF), total of species (TE) and total number of individuals (TNI). The result was further subjected to statistical analysis using non-parametric indices of the following faunistic indexes: (a) Diversity Index (H) proposed by Margalef (1947) and (b) Coefficient of Similarity (QS) proposed by Sorensen (1948), both cited in Silveira Neto et al. (1976). The diversity index (a) is represented by $\mathrm{H}=\mathrm{S}-1 / \mathrm{LN}(\mathrm{H}=$ diversity index, $\mathrm{S}=$ number of taxa; $\mathrm{LN}=$ natural logarithm of the number of individuals), while the similarity coefficient (b) is expressed by QS $=2 \mathrm{~J} / \mathrm{a}+\mathrm{b}(\mathrm{J}=$ number of taxa found in both areas, $\mathrm{a}=$ number of taxa in area $\mathrm{A}$ and $b=$ number of taxa in area B). The main objective of characterization of communities through faunal indices, is to verify the momentary stability of an ecosystem, and can be used in comparative studies on different ecosystems (Romano, 2003).

\section{Results}

A total of 3,440 individuals belonging to the classes Insecta, Arachnida, Diplopoda and Chilopoda was collected. The class Insecta was the most representative with 3,271 individuals, followed by the class Arachnida with 110 individuals. Millipedes and Centipedes had, respectively, 57 and 2 individuals collected.

As for the insects, 12 orders were found, consisting of 26 families. The evaluated variables shown in Table 1 and the diversity index were higher in the preserved area. The similarity coefficient calculated reveals only $10 \%$ of similarity related to insects found in the areas, with only 12 species simultaneously occurring in both areas. In most of the families, the largest number of individuals was found in the preserved area. (Table 2). The arachnids found in both areas differed in terms of number of families and total number of individuals, being considerably higher in the preserved area (Table 3). The diversity 
Table 1 - Variables assessed for the class Insecta in the study areas.

\begin{tabular}{llccccc}
\hline Collection areas & NO & NF & NE & TNI & H & QS (\%) \\
\hline Area of pasture & 10 & 19 & 98 & 1548 & 13.21 & 10 \\
Preserved area & 12 & 21 & 114 & 1723 & 15.16 & \\
\hline
\end{tabular}

$\mathrm{NO}=$ Number of order $\mathrm{NF}=$ Number of family; $\mathrm{NE}=$ Number of species, $\mathrm{TNI}=$ total number of individuals, $\mathrm{H}=$ Diversity Index, QS = coefficient of similarity.

Table 2 - Number of individuals per family and frequency of the families of the class Insecta found in the study areas.

\begin{tabular}{|c|c|c|c|c|c|}
\hline \multicolumn{2}{|c|}{ Groups of Insecta } & \multicolumn{2}{|c|}{ Pasture area } & \multicolumn{2}{|c|}{ Preserved Area } \\
\hline Order & Family & $\mathbf{N}$ & $\mathbf{F} \%$ & $\mathbf{N}$ & $\mathbf{F} \%$ \\
\hline \multicolumn{6}{|c|}{ Coleoptera } \\
\hline & Carabidae & 134 & 26.9 & 76 & 11.2 \\
\hline & Curculionidae & 11 & 2.2 & 214 & 31.6 \\
\hline & Scarabaeidae & 181 & 36.3 & 295 & 43.6 \\
\hline & Coccinellidae & 44 & 8.8 & 44 & 6.5 \\
\hline & Staphylinidae & 25 & 5 & 5 & 0.7 \\
\hline & Tenebrionidae & 19 & 3.8 & 2 & 0.3 \\
\hline & Elateridae & 72 & 14.4 & 0 & 0 \\
\hline & Lampyridae & 2 & 0.4 & 0 & 0 \\
\hline & Other & 10 & 2 & 13 & 1.9 \\
\hline \multicolumn{6}{|c|}{ Hymenoptera } \\
\hline & Formicidae & 899 & 99.2 & 338 & 98.8 \\
\hline & Apidae & 0 & 0 & 1 & 0.3 \\
\hline & Mutillidae & 6 & 0.7 & 2 & 0.6 \\
\hline & Ichneumonidae & 0 & 0 & 1 & 0.3 \\
\hline & Pompilidae & 1 & 0.1 & 0 & 0 \\
\hline \multicolumn{6}{|c|}{ Orthoptera } \\
\hline & Gryllidae & 21 & 43.8 & 61 & 96.8 \\
\hline & Acrididae & 13 & 27.1 & 2 & 3.2 \\
\hline & Proscopiidae & 5 & 10.4 & 0 & 0 \\
\hline & Other & 9 & 18.8 & 0 & 0 \\
\hline \multicolumn{6}{|c|}{ Lepidoptera } \\
\hline & Noctuidae & 3 & 20 & 31 & 91.2 \\
\hline & Brassolidae & 0 & 0 & 1 & 2.9 \\
\hline & Pyralidae & 1 & 6.7 & 0 & 0 \\
\hline & Hesperiidae & 0 & 0 & 1 & 2.9 \\
\hline & Other & 11 & 73.3 & 1 & 2.9 \\
\hline \multicolumn{6}{|l|}{ Diptera } \\
\hline & Sarcophagidae & 4 & 18.2 & 0 & 0 \\
\hline & Culicidae & 0 & 0 & 1 & 11.1 \\
\hline & Dolichopodidae & 0 & 0 & 7 & 77.7 \\
\hline & Other & 18 & 81.8 & 1 & 11.1 \\
\hline \multicolumn{6}{|c|}{ Hemiptera } \\
\hline & Cydnidae & 0 & 0 & 7 & 35 \\
\hline
\end{tabular}


Table 2 (cont.)

\begin{tabular}{|c|c|c|c|c|c|}
\hline \multicolumn{2}{|c|}{ Groups of Insecta } & \multicolumn{2}{|c|}{ Pasture area } & \multicolumn{2}{|c|}{ Preserved Area } \\
\hline Order & Family & $\mathbf{N}$ & F\% & $\mathbf{N}$ & F\% \\
\hline & Corizidae & 5 & 55.6 & 0 & 0 \\
\hline & Other & 4 & 44.4 & 13 & 65 \\
\hline \multicolumn{6}{|c|}{ Isoptera } \\
\hline & Termitidae & 0 & 0 & 231 & 99.6 \\
\hline & Other & 2 & 100 & 1 & 0.4 \\
\hline \multicolumn{6}{|c|}{ Neuroptera } \\
\hline & Myrmeleontidae & 0 & 0 & 2 & 100 \\
\hline \multicolumn{6}{|c|}{ Dermaptera } \\
\hline & Not identified & 41 & 100 & 286 & 100 \\
\hline \multicolumn{6}{|c|}{ Blattodea } \\
\hline & Blattidae & 6 & 100 & 47 & 100 \\
\hline \multicolumn{6}{|c|}{ Mantodea } \\
\hline & Mantidae & 1 & 100 & 9 & 100 \\
\hline \multicolumn{6}{|c|}{ Thysanura } \\
\hline & Not identified & 0 & - & 3 & 100 \\
\hline
\end{tabular}

$\mathrm{N}=$ number of individuals, $\mathrm{F}=$ frequency.

Table 3 - Variables assessed for the class Arachinida in the study areas.

\begin{tabular}{lcccc}
\hline Collection areas & NO & NF & TNI & H \\
\hline Pasture area & 1 & 6 & 48 & 1.29 \\
Preserved area & 2 & 12 & 62 & 2.66 \\
\hline
\end{tabular}

$\mathrm{NO}=$ Number of orders $\mathrm{NF}=$ Number of families, $\mathrm{TNI}=$ total number of individuals, $\mathrm{H}=$ Diversity Index.

found within the preserved area was also higher (Table 4). With respect to the classes Chilopoda and Diplopoda, in the pasture area only one species of millipedes and centipede was found, while in the preserved area it was verified the presence of seven species of millipedes and one centipede. Since the number of centipedes species was the same for both areas, the index of diversity and similarity coefficient for that group were not calculated. For millipedes, however, the diversity index was higher in the preserved area, and the similarity coefficient $(33 \%)$ was calculated taking into account the number of species (Table 5).

\section{Discussion}

Although an area of permanent pasture, according to Silva et al. (2006), is still a practice of soil management that encourages the dynamics of organic matter when compared with other agricultural practices that occur in intensive soil management, remarkable differences between the preserved and the managed with pasture areas related to the different groups of arthropods of these two ecosystems were verified. This result may be associated with the lower amount of plant residues in the pasture area. According to Leiva (2008), areas with uniform and thicker litter have higher abundance of invertebrates, indicating the importance of this substrate both as food resource and refuge site.

Insects, especially orders with the greater diversity of species (Barbieri Jr. and Dias, 2012), are widely used to assess the conservation status of ecosystems. Among the beetles, the most frequent families were Carabidae and Scarabaeidae. The first one, especially in the pasture area, and the second one more frequent in the preserved area. Dung beetles are sensitive to changes in habitat, since they have low dispersal ability, specialized diet, based mainly on mammalian excreta, and display distribution strongly influenced by vegetation cover (Halter and Arellano, 2002, Costa et al., 2009, Azevedo et al., 2011). This explains the larger amount of the insects collected in the preserved area. On the other hand, it is interesting to note that carabids were collected in greater quantities in the pasture, contrary to the principle that the population of these insects is often negatively affected by grazing management practices (Rainio and Niemelä, 2003.) Representatives of the family Carabidae are predators, occupying higher trophic levels. These levels are generally quite sensitive to environmental changes, since they depend on others for survival. However, this seems to have been an exception among the results, since other taxa with several predator species, such as Mantidae, Dermaptera, Myrmeleontidae and Coccinellidae, were found in greater quantity in the preserved area. Yet, the 
Edaphic arthropods in two different areas in Teresina, PI, Brazil

Table 4 - Number of individuals per family and frequency of families in class Arachinida in the study areas.

\begin{tabular}{|c|c|c|c|c|c|}
\hline \multicolumn{2}{|c|}{ Gruops of Arachnida } & \multicolumn{2}{|c|}{ Pasture area } & \multicolumn{2}{|c|}{ Preserved area } \\
\hline Order & Family & $\mathbf{N}$ & F\% & $\mathbf{N}$ & $\mathbf{F} \%$ \\
\hline \multicolumn{6}{|l|}{ Araneae } \\
\hline & Araneidae & 0 & 0 & 3 & 5 \\
\hline & Corinnidae & 7 & 14.6 & 3 & 5 \\
\hline & Ctenidae & 6 & 12.5 & 27 & 45 \\
\hline & Dipluridae & 0 & 0 & 3 & 5 \\
\hline & Gnaphosidae & 0 & 0 & 1 & 1.7 \\
\hline & Idiopidae & 0 & 0 & 3 & 5 \\
\hline & Lycosidae & 25 & 52.1 & 6 & 10 \\
\hline & Pholcidae & 0 & 0 & 3 & 5 \\
\hline & Salticidae & 5 & 10.4 & 66 & 10 \\
\hline & Theraphosidae & 1 & 2.1 & 0 & 0 \\
\hline & Zodariidae & 4 & 8.3 & 5 & 8.3 \\
\hline Scorpionidae & Not identified & 0 & 0 & 2 & 100 \\
\hline
\end{tabular}

$\mathrm{N}=$ number of individuals, $\mathrm{F}=$ frequency.

Table 5 - Number of species, individuals and faunistic indexes of the classes Diplopoda and Chilopoda in the study areas.

\begin{tabular}{lccccccccc}
\hline & \multicolumn{3}{c}{ Pasture area } & & \multicolumn{3}{c}{ Preserved area } & \multirow{2}{*}{ QS (\%) } \\
\cline { 2 - 4 } \cline { 6 - 8 } Class & NE & TNI & H & & NE & TNI & H & \\
\hline Diplopoda & 1 & 31 & - & & 7 & 26 & 1.84 & 33 \\
Chilopoda & 1 & 1 & - & & 1 & 1 & - & - \\
\hline
\end{tabular}

$\mathrm{NE}=$ Number of species, $\mathrm{TNI}=$ total number of individuals, $\mathrm{H}=$ diversity index. $\mathrm{QS}=$ similarity coefficient.

number of Curculionidae was considerably higher in the preserved area, and Elateridae and Lampyridae were not found in the preserved area.

Among the Hymenoptera, the family Formicidae showed frequency of $99.2 \%$ and $98.8 \%$, respectively, in the managed and preserved areas, and, although the number of ants was higher in the pasture area, the number of species was greater in the preserved area. According Wink et al. (2005), Formicidae corresponds to a dominant taxonomic group in most ecosystems, present in several habitats. Also according to the author, the disturbances in forest environments may favor the onset of opportunistic ants, among them, Dolichoderineae. Some Myrmicinae species, on the other hand, are commonly found in undisturbed places (King et al., 1998). Smith et al. (2001) states that the species richness of ants is correlated with the type and variety of vegetation, increasing in areas with more complex vegetation. Freitas et al. (2006) suggests that ants may be present in high numbers in areas altered by increased food availability and decrease of predators, which explains why they have been collected in much larger amount in the pasture.
The results for carabids and ants differ from Cividanes (2002). This author compared the occurrence of phytophagous arthropods and predators in different soil management systems and found higher number of these individuals in areas with lower soil management.

As for Orthoptera, Gryllidae was found more frequently in the preserved area $(96.8 \%)$. This result is in agreement with Hook (1971), who found lower density of crickets in pasture areas, probably due to mortality caused by spiders.

It is worth mentioning the presence of the family Termitidae in the preserved area, since none was found in pasture area. Lima et al. (2011), however, state that, althgough possible, there is no concrete evidence that the existence of termites in one area is an indication of degradation of pasture.

The other groups of Insecta were poorly sampled, and it was not possible to infer about the state of conservation of the area based on these data. However, the coefficient of similarity $(10 \%)$ indicates a significant difference between the two study areas.

The arachnids are predators and are related to more diverse habitats. The structure of microhabitat is also rel- 
evant, and litter type and depth are important for providing hunting and foraging niches and for protection from predators and desiccation (Pearce and Venier, 2006). This explains their high rate of diversity in the preserved area (Table 3). Out the eleven families of spiders found in the preserved area, only five were present in the area managed with pasture (Table 4).

Chilopoda and Diplopoda were not collected in large quantities, thus it was not possible infer about its meaning in relation to the conservation state of the areas, although the millipedes diversity index has also been largest in the preserved area.

Studies evaluating the density and diversity of arthropods in different types of soil management, usually results in greater numbers within less managed and with more complex vegetation areas, compared with simplified vegetation areas, such as monocultures (Ferreira \& Marques, 1998, Silva et al., 2006). This was also observed in this work.

Silva et al. (2006) compared the diversity of invertebrate soil macrofauna in croppping systems, including permanent pasture with Cerrado vegetation. They noticed that the native vegetation had the highest overall density and diversity of groups, due to being a more favorable environment taking into account variety of microhabitats and supply of natural resources.

In our study, it is clear that the intensive use of land with livestock purposes probably induced changes in soil fauna of arthropods. Groups important to maintain the balance of any ecosystem, as predators and decomposers of organic matter, had populations reduced in this area, while the population of ants, for example, was far greater. The higher diversity indexes in the preserved area, and the similarity coefficients, verified the difference between the fauna of these animals in both areas. This result agrees with the studies of Attwood et al. (2008), who observed a general decline in arthropod richness with increasing intensity of land use and management.

Yet, our study shows interference from vegetation removal and soil management on soil arthropod groups of the studied communities. The diversification of plant species promotes a greater diversification of most groups of soil arthropods. Therefore, the use of lands for livestock for long periods decreases the diversity of soil arthropod fauna. Since these animals are very important on the environment for nutrient cycling, pest control, pollination and maintenance of soil structure, their conservation must be encouraged.

\section{Acknowledgments}

To MSc. Ocimar Barbosa and MSc. Rommel Castelo Branco, from Centro de Ciências Agrárias (CCA/UFPI) for helping with the identification of insects; to Biol. Eduardo Marques, from Centro de Ciências da Natureza (CCN/UFPI) for his assistance in this work.

\section{References}

ALTIERI, M., SILVA, EN., NICHOLLS, CI., 2003. O Papel da Biodiversidade no Manejo Integrado de Pragas. Ribeirão Preto: Holos. 226 p.

ATTWOOD, SJ., MARON, M., HOUSE, APN. and ZAMMIT, C., 2008. Do arthropod assemblages display globally consistent responses to intensified agricultural land use and management? Global Ecology and Biogeography, vol. 17, p. $585-599$.

AZEVEDO, FR, MOURA, MAR., ARRAIS, MSB. and NERE, DR., 2011. Composição da entomofauna da Floresta Nacional do Araripe em diferentes vegetações e estações do ano. Ceres, vol. 58, n. 6, p. 740-748.

BARBIERI JUNIOR, CA. and DIAS, AMP., 2012. Braconidae (Hymenoptera) fauna in native, degraded and restoration areas of the Vale do Paraíba, São Paulo state, Brazil. Brazilian Journal of Biology, vol. 72, n. 2, pp. 305-310.

CIVIDANES, FJ., 2002. Efeitos do sistema de plantio e da consorciação soja-milho sobre artrópodes capturados no solo. Pesquisa Agropecuária Brasileira, vol. 37, p. 15-23.

COODINGTON, JA., GRISWOLD, CE., DÁVILA, DS., PEÑARANDA, E. and LARCHER, SF., 1991. Designing and Testing Sampling Protocols to Estimate Biodiversity in Tropical Ecosystems. In Dudley, EC. (Ed.). The Unity of Evolutionary Biology: Proceedings of the fourth International Congress of Systematic and Evolutionary Biology. Portland: Dioscorides Press. p. 40-60.

COSTA, CMQ., SILVA, FAB., FARIAS, AI. and MOURA, RC., 2009. Diversidade de Scarabaeinae (Coleoptera, Scarabaeidae) coletados com armadilha de interceptação de vôo no Refúgio Ecológico Charles Darwin, IgarassuPE, Brasil. Revista Brasileira de Entomologia. vol. 53, n. 1, p. 88-94.

FAVERO, S., SOUZA, HA. and OLIVEIRA, AKM., 2011. Coleoptera (Insecta) as forest fragmentation indicators in the Rio Negro sub-region of the Pantanal, Mato Grosso do Sul, Brazil. Brazilian Journal of Biology, vol. 71, n. 1, suppl. 1, p. 291-295.

FERREIRA, RL. and MARQUES, MMGSM., 1998. A Fauna de Artrópodes de Serrapilheira de Áreas de Monocultura com Eucalyptus sp. e Mata Secundária Heterogênea. Anais da Sociedade Entomológica do Brasil, vol. 27, n. 3, p. 395-403.

FREITAS, AVL. LEAL, I. R., UEHARA-PRADO, M. and IANNUZZI, L., 2006. Insetos como indicadores de conservação da paisagem. In: ROCHA, CFD., BERGALO, HG., SLUYS, MV. and ALVES, MAS. (eds). Biologia da Conservação: essências. São Carlos: Rima. p. 357-384.

HALTER, G. and ARELLANO, L., 2002. Response of dung beetle diversity to human induced changes in a tropical landscape. Biotropica, vol. 34, p. 144-154.

HÖFER, H., HANAGART, W., GARCIA, M., MARTIUS, C., FRANKLIN, E., RÖMBKE, J. and BECK, L., 2001. Struture and function of soll fauna communities in Amazonian anthropogenic and natural ecosystems. Euro Journal of Soil Biology, vol. 37, p. 229-235.

HOOK, RI., 1971. Energy and nutrient dynamics of spider and orthopteran populations in a grassland ecosystem. Ecological Monographs, vol. 41, p. 1-26.

KING, JR, ANDERSEN, AN. and CUTTER, AD., 1998. Ants as bioindicators of habitat disturbance: validation of the functional group model for Australia's humid tropics. Biodiversity and Conservation, vol. 7, p. 1627-1638.

LIMA, SS., ALVES, BJR., AQUINO, AM., MERCANTE, FM., PINHEIRO, EFM., SANT'ANNA, SAC., 
URQUIAGA, S. and BODDEY, R.M., 2011. Relação entre a presença de cupinzeiros e a degradação de pastagens. Pesquisa Agropecuária Brasileira, vol. 46, n. 12, p. $1699-1706$.

PAOLETTI, MG., BRESSAN, M. and EDWARDS, CA., 1996. Soil invertebrates as bioindicators of human disturbance. Critical Reviews in Plant Sciences, vol. 15, n. 1, p. 21-62.

PARISI, V., MENTA, C., GARDI, C., JACOMINI, C. and MOZZANICA, E., 2005. Microarthropod communities as a tool to assess soil quality and biodiversity: a new approach in Italy. Agriculture, Ecosystems and Environment, vol. 105, p. 323-333.

PEARCE, JL. and VENIER, LA., 2006. The use of ground beetles (Coleoptera: Carabidae) and spiders (Araneae) as bioindicators of sustainable forest management: a review. Ecological Indicators, vol. 6, p. 780-793.

RAINIO, J. and NIEMLÄ, J., 2003. Ground beetles (Coleoptera: Carabidae) as bioindicators. Biodiversity and Conservation, vol. 12, p. 487-506.

ROMANO, FC., 2003. Comparação de insetos na cultura do feijoeiro cultivado nos sistemas orgânicos e convencional. Botucatu: Universidade Estadual Paulista. 87 p. Dissertação de Mestrado em Agronomia.

SANTORUFO, L., VAN GESTEL, C.A.M., ROCCO, A. and MAISTO, G., 2012. Soil invertebrates as bioindicators of urban soil quality. Environmental Pollution, vol. 161, p. $57-63$
SANTOS, AJ., 1999. Diversidade e Composição em Espécies de Aranhas da Reserva Florestal da Companhia do Vale do Rio Doce (Linhares - ES). Campinas: Universidade Estadual de Campinas. 105 p. Dissertação de mestrado em Ciências Biológicas.

SAMWAYS, M. J., 1994. Insect Conservation Biology. London: Chapman and Hall. 358 p.

SILVA, RF., AQUINO, AM., MERCANTE, FM. and GUIMARÃES, MF., 2006. Macrofauna invertebrada do solo sob diferentes sistemas de produção em Latossolo da região do Cerrado. Pesquisa Agropecuária Brasileira, vol. 41, p. $697-704$

SILVEIRA NETO, S., NAKANO, O., BARBIN, D. and VILA NOVA, NA., 1976. Manual de ecologia dos Insetos. São Paulo: Agronômica Ceres. 419 p.

SOARES, IMF., GOMES, DS. and SANTOS, AA., 2001. Influência da composição florística na diversidade de formigas (Hymenoptera: Formicidae) na Serra da Jibóia-BA. In $15^{\circ}$ Encontro de Mirmecologia. Londrina: IAPAR, 2001. p. 331-332.

SOCORRAS, A., 1998. La vida del Suelo: un indicador de su fertilidad. Agricultura orgânica, vol. 4, n. 1, p. 12-14.

VAN STRAALEN, NM., 1998. Evaluation of bioindicator systems derived from soil arthropod communities. Applied Soil Ecology, vol. 9, p. 429-437.

WINK, C., GUEDES, JVC., FAGUNDES, CK. and ROVEDDER, AP., 2005. Insetos edáficos como indicadores da qualidade ambiental soilborne insects as indicators of environmental quality. Revista de Ciências Agroveterinárias, vol. 4, n. 1, p. 60-71. 